\title{
粉砕樹脂充てんエポキシ樹脂の硫酸水溶液中での腐食挙動†
}

\author{
仙北谷 英 貴* 白 石 文 洋** \\ 久保内 昌 敏* 津 田健*

\section{Corrosion Behavior of Epoxy Resin Filled with Ground Resin in Sulfuric Acid Solution}

\author{
by \\ Hideki SembokuYa ${ }^{*}$, Fumihiro Shiraishi ${ }^{* *}$, Masatoshi Kubouchi ${ }^{*}$ and Ken Tsuda ${ }^{*}$
}

\begin{abstract}
An epoxy resin cured with acid anhydride has good resistance to acid solution and an epoxy resin cured with amine has poor resistance. Two types of ground fillers were made from these two types of epoxy resins. Four kinds of recycled materials composed of two types of fillers and two types of matrix resins were prepared. The corrosion behaviors of the four kinds of particle filled epoxy resins (and other two types of neat resins) in sulfuric acid solution were investigated. In case the matrix was an epoxy resin cured with acid anhydride, flexural strength after immersion test in sulfuric acid solution normalized by that in pure water did not decrease for the neat epoxy resin and the recycled material filled with particles of epoxy resin cured with acid anhydride. With respect to the recycled material filled with particles of epoxy resin cured with amine, the normalized flexural strength decreased by degradation of exposed filler on the surface of specimen. On the other hand, in case the matrix was an epoxy resin cured with amine, the weight and thickness noticeably increased by immersing in sulfuric acid solution for the neat epoxy resin, the recycled material filled with particles of epoxy resin cured with acid anhydride and the recycled material filled with particles of epoxy resin cured with amine. For the three kinds of materials, the retention of flexural strength of dried specimens increased immediately after immersion tests started and then decreased. Sulfuric acid penetrated into all materials as results of X-ray elemental analysis. There was no distinct difference in decrease of strength of three kinds of materials and penetration of sulfuric acid into them.
\end{abstract}

Key words : Corrosion, Recycle, Epoxy, Filler, Composite materials, Acid, Degradation, Strength

\section{1 緒}

エポキシ樹脂などの熱硬化性樹脂は, 化学構造が 3 次 元のネットワーク構造となるため, 加熱溶融と冷却固化 によるリサイクルが原理的に不可能である。このため， 樹脂硬化物を粉砕した粒子を，例えば増量剤などの用途 として未硬化樹脂等に充てんする方法が現実的なリサイ クル方法である.1. 2)

一般的に, 熱硬化性樹脂は金属材料と比較して耐薬品 性, 特に耐酸性に優れることから, 金属材料の防食材と してあるいは耐食 FRPのマトリクスとして幅広く使用さ れている。将来的には，このような過酷な環境で使用さ れる樹脂についてもリサイクル材料を用いることが望ま れるが，少なくとも，現在の熱硬化性樹脂の主要な用途 である浴槽や船艇のような軽度の腐食環境に対しては十 分な耐食性を有することが必要である。しかしながら， 粉砕粒子充てんタイプのリサイクル材料については, 力 学的特性についての研究は行われているが, 化学的耐久 性に関する報告は少ない.

著者らはこれまで，アルミナなどの無機系粒子を充て んした高分子材料の腐食挙動に関する研究を行い, ${ }^{4}$ 腐食
速度に及ぼす平均粒子径の影響は小さいが，充てん率の 影響は非常に大きいことを明らかにした. ${ }^{5)}$ ブレンドポリ マーの場合には，耐食性の高い分散相の導入によって材 料全体の耐食性が向上する場合があるが, 硬質粒子充て ん複合材料に関してはフレークのような例外 ${ }^{7)}$ を除いて 耐食性は概して低下する。これは, 界面の存在により環 境液の浸入が促進されるからであり, 粉砕粒子充てん樹 脂に関しても，耐食性が低下する可能性がある.

ところで, 代表的な熱硬化性樹脂のひとつであるエポ キシ樹脂は, 硬化剤の種類によって酸無水物硬化エポキ シ樹脂とアミン硬化エポキシ樹脂とに大別できる，耐食 性はこの硬化剤の種類によって大きく異なり, 概略的に 言うと酸無水物硬化タイプはアルカリに，アミン硬化タ イプは酸に対して腐食を受けやすい. 扣いて両者の分別を行うのは非現実的なので，粉砕リサ イクルを行った場合, 酸無水物硬化エポキシ樹脂の粒子 とアミン硬化エポキシ樹脂の粒子が混在することになる. このような粒子をエポキシ樹脂に充てんした場合，フィ ラーとマトリクスの耐食性の傾向が異なるため, 耐化学 薬品性の観点から見ると明確な界面が存在することにな

$\dagger \quad$ 原稿受理 平成 14 年 11 月 1 日 Received Nov. 1, 2002

* 正会 員 東京工業大学大学院理工学研究科化学工学専攻 $₹ 152-8552$ 目黒区大岡山, Dept. of Chem. Eng., Tokyo Inst. of Tech., Meguro-ku, Tokyo, 152-8552

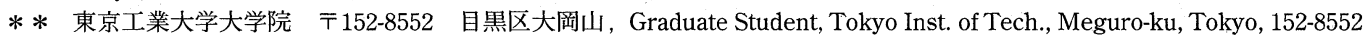


る.すると，無機系粒子充てん材料において観察された ような耐食性の低下が起こることが予想されるが ${ }^{9}$ )この ような観点での研究は全く見当たらない.

そこで本研究では，アミン硬化エポキシ樹脂を粉砕し た粒子と，酸無水物硬化エポキシ樹脂を粉砕した粒子を 用意し，これをそれぞれアミン硬化エポキシ樹脂あるい は酸無水物硬化エポキシ樹脂に充てんした 4 種類の粒子 充てん樹脂を成形して, 硫酸水溶液中での腐食挙動を検 討した。

\section{2 実験}

\section{$2 \cdot 1$ 試験材料および試験片}

本研究では, エポキシ樹脂主剤を酸無水物およびアミ ンで硬化させた 2 種類のエポキシ樹脂を使用した。 エポ キシ樹脂主剤には, 共通のビスフェノール $\mathrm{A}$ 型エポキシ 樹脂を用いた。酸無水物系硬化剛にはメチルテトラヒド 口無水フタル酸を, アミン系硬化剂には複素環式ジアミ ン変性物を用いた。酸無水物系については, 主㓮：硬化 剤：硬化促進剤（トリスジメチルアミノメチルフェノー ル） $100: 80: 1$ で混合し, 1 次硬化を $80^{\circ} \mathrm{C} て ゙ ~ 3$ 時間, 2 次硬化を $120^{\circ} \mathrm{C} て ゙ 6$ 時間行って硬化させた，以後，こ の樹脂単体の酸無水物硬化エポキシ樹脂を「酸硬化バー ジン材」と呼ぶこととする。アミン系については，主 剤：硬化剤：消泡剂を $100 ： 50 ： 0.1$ で混合し，1 次硬化 を $25^{\circ} \mathrm{C} て ゙ ~ 24$ 時間, 2 次硬化を $80^{\circ} \mathrm{C}$ で 3 時間行って硬化 させた，以後，この材料を「アミン硬化バージン材」と 呼ぶ.

次にフィラーであるが，厚さ 2 または $3 \mathrm{~mm}$ の平板状 に成形したバージン材を高速切断機で $20 \mathrm{~mm}$ 角に切断 し，さらに小型高速回転式衝撃粉碎機を用いて約 $1 \sim 2$ 分粉砕した。呼び径 $1 \mathrm{~mm}$ のふるいを通過した不定形粒 子を回収して充てん用フィラーを得た. ${ }^{10}$ 酸硬化バージン 材打よびアミン硬化バージン材に対応した粒子をそれぞ れ「酸フィラー」および「アミンフィラー」と呼ぶこと とする.

これら 2 種類のフィラーをそれ父れ酸無水物硬化エポ キシ樹脂打よびアミン硬化エポキシ樹脂に充てんし，4種 類のリサイクルエポキシ樹脂硬化物を得た．名称の煩雑 さを避けるため, 例えば酸フィラー充てんアミン硬化工 ポキシ樹脂については, フィラーの材料名を前に, マト リクスを後に書くこととして，「酸/アミンリサイクル材」 などのように略すこととする．すなわち，得られた 4 種 類の材料は「酸／酸リサイクル材」,「アミン／酸リサイ クル材」,「酸/アミンリサイクル材」,「アミン/アミン リサイクル材」の 4 種類である. フィラーの体積含有率 $\mathrm{V}_{\mathrm{f}}$ は $20 \%$ とした， $\mathrm{V}_{\mathrm{f}}$ に関しては，リサイクルが目的であ ることから可能な限り大きな値にしたいところであるが， 既報 ${ }^{10)}$ で示したように $20 \%$ 以上充てんすると成形の困難 さによる力学的特性の低下が見られた。 これらの材料を 用いて，厚さ 2 または $3 \mathrm{~mm}$ の平板を成形し， $60 \times 25 \mathrm{~mm}$ に切り出したものを試験片とした。 な抏，成形後のリサイ クル材を目視で観察したところ, バージン材と同様に透明 であり, 粒子の存在は外見上は確認できなかった。
2 種類のバージン材打よび 4 種類のリサイクル材の力 学的特性を Table I に示す. サンプル数は 5 個である. 曲 げ弾性率に関しては，いずれの材料に打いてもほ同様の 值であったが, 曲げ強度に関しては, リサイクル材の強度 はバージン材と比較して若干低下する傾向があった。

\section{$2 \cdot 2$ 試験方法}

$30 \mathrm{wt} \%$ 硫酸水溶液を満たしたビーカーの中に試験片を 入れ，このビーカーを $80 \pm 0.1^{\circ} \mathrm{C} に$ 保たれた恒温水槽中 に静置することにより浸せき試験を行った. ${ }^{10}$ 試験片は浸 せき後適時取り出し, イオン交換水で洗浄後表面の水分 を拭き取り，空気中に 1 時間放置した後重量を測定し， これを湿潤重量とした，試験片の寸法を測定した後，湿 潤状態のまま 3 点曲げ試験を行って, 得られた強度を湿 潤曲げ強度とした，また，浸せき後同様に洗浄したもの を $50^{\circ} \mathrm{C} に$ 保たれた乾燥器中で恒量になるまで (約 1 週間) 乾燥した重量を乾燥重量とした。ささらに 3 点曲げ試験を 行って得た值を乾燥曲げ強度とした。曲げ試験は ASTMD790 に準拠し，スパン間隔 $40 \mathrm{~mm}$ ，クロスヘッド速度 $2 \mathrm{~mm} / \mathrm{min}$, 室温, 大気中で行った。 な扐，曲げ強度に ついては, すべて浸せき前の曲げ強度で無次元化して曲 げ強度保持率で評価した。

\section{3 実験結果および考察}

\section{$3 \cdot 1$ 酸無水物硬化エポキシ樹脂をマトリクスとする 材料の腐食挙動}

まず，酸無水物硬化エポキシ樹脂をマトリクスとする 3 種類の材料, すなわち酸硬化バージン材, 酸/酸リ少 イクル材およびアミン／酸リサイクル材について述べる. 緒言で述べたように, 酸無水物硬化エポキシ樹脂は耐酸 性に優れているのが特徴である.

$80^{\circ} \mathrm{C}, 30 \mathrm{wt} \%$ 硫酸水溶液に浸せきした後の試験片の様 相を観察したところ, 酸硬化バージン材と酸／酸リサイ クル材では外見上の変化は観察されなかった。一方，耐 酸性の低いフィラーを充てんしたアミン／酸リサイクル 材では, 表面に露出しているアミンフィラーが赤褐色に 変色し, 顕著に膨潤して試験片表面から粒状に隆起して いる様相が観察された。

3 種類の材料を硫酸水溶液中に浸せきした場合の湿潤 重量（取り出し直後の重量）の経時変化を Fig. 1 に示 す.いずれの材料においても，浸せき直後にわずかに湿 潤重量が増加し一定値になっている. 詳細に見るとアミ ン/酸リサイクル材の重量増加が若干多いが, これは試 験片表面のアミンフィラーの膨潤によるものである。こ

Table I. Mechanical properties of the filler/matrix materials.

\begin{tabular}{lcc}
\hline & $\begin{array}{c}\text { Flexural strength } \\
\text { [MPa] }\end{array}$ & $\begin{array}{c}\text { Flexural modulus } \\
{[\mathrm{GPa}]}\end{array}$ \\
\hline Acid virgin & 140 & 3.42 \\
Acid/acid recycle & 122 & 3.48 \\
Amine/acid recycle & 132 & 3.36 \\
Amine virgin & 128 & 3.33 \\
Amine/amine recycle & 126 & 3.36 \\
Acid/amine recycle & 105 & 3.27 \\
\hline
\end{tabular}




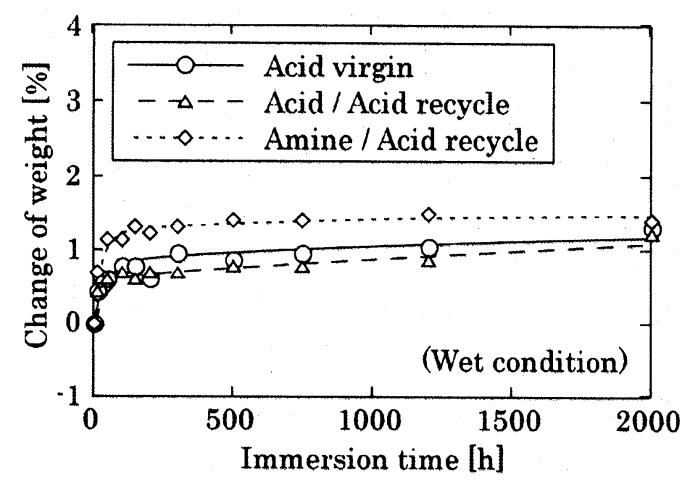

Fig. 1. Weight change after immersion test in $30 \mathrm{wt} \%$ $\mathrm{H}_{2} \mathrm{SO}_{4}$ at $80^{\circ} \mathrm{C}$ for the materials of which matrices are epoxy resin cured with acid anhydride.

れら 3 種類の試験片の乾燥重量の経時変化を測定したと ころ，いずれの浸せき時間においても，ほぼ浸せき前の 值に戻っていることがわかった。硫酸分子が材料内に浸 入している場合には乾燥重量の増加が認められるが ${ }^{11)}$ 本 研究の酸無水物硬化エポキシ樹脂をマトリクスとした系 ではそのような重量増加は観察されず，基本的に重量増 加が水のみの浸入によるものであることが示唆される. また, 試験片の外観変化の観察において, アミン／酸り サイクル材のアミンフィラーの膨潤が観察されたが, こ のような現象は表面近傍のみで発生しているため, 重量 増加に及ぼす影響は小さかった。

3 種類の材料の湿潤曲げ強度保持率を求めたところ, いずれの材料に打いても浸せき直後から強度が低下し， 約 300 時間で一定值となった. 強度が最も著しく低下し たのはアミン／酸リサイクル材であり, 次が酸／酸リサ イクル材であった。酸硬化バージン材が最も高い強度を 維持していた. 次に, 乾燥曲げ強度保持率の経時変化を Fig. 2 に示す. ややばらつきが大きいが, 乾燥強度にお いても湿潤強度とほぼ同様の傾向を示し，いずれの材料 においても浸せき直後から乾燥曲げ強度保持率が低下し た. 強度低下の順番も湿潤強度と同じであった。

ところで, 酸無水物硬化エポキシ樹脂は, 純水中にお いても強度低下が起こる場合があることから，前述の強 度低下も水の影響があることが考えられる，そこで Fig. 3

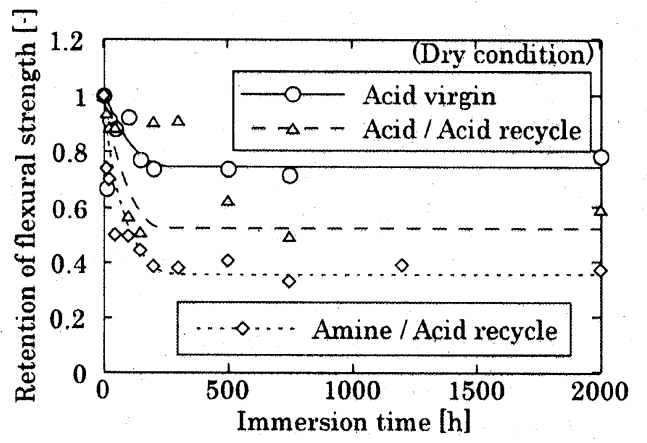

Fig. 2. Retention of flexural strength after immersion test in $30 \mathrm{wt} \% \mathrm{H}_{2} \mathrm{SO}_{4}$ at $80^{\circ} \mathrm{C}$ for the materials of which matrices are epoxy resin cured with acid anhydride.
に, 純水中に浸せきした 3 種類の材料の乾燥曲げ強度保 持率の経時変化を示した，いずれの材料に扔いても, 浸 せき直後から強度が低下し，約 200 時間で一定值になっ ている. 酸硬化バージン材の強度低下は小さく，それと 比較してリサイクル材の強度低下はやや顕著であった。

本研究で用いた $30 \mathrm{wt} \%$ の硫酸水溶液は非常に過酷な環 境であるが，それでも硫酸分子と水分子のモル比は約 1:18であり, 酸無水物硬化エポキシ樹脂のように純水 中でも強度低下が起こる場合には, 硫酸水溶液中につい

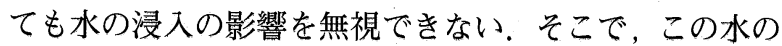
影響を除去するため, Fig. 2 の硫酸水溶液中での曲げ強 度保持率をFig. 3 の純水中における值で除して規格化 し，その経時変化を Fig. 4 に示した. 図より, 酸硬化バ ージン材およひ酸／酸リサイクル材の規格化曲げ強度は 浸せき後もほぼ 1 であり，硫酸水溶液中での強度低下が 単に水の浸入によるものであることがわかる，一方，ア ミン／酸リサイクル材では, 規格化曲げ強度が大きく低 下している。これは，表面に露出したアミンフィラーが 硫酸によって攻撃を受けて強度が著しく低下したため， アミンフィラーの存在していた部分が空洞として作用し， これらが応力集中源となって強度が低下していたと考え られる，なお，酸無水物硬化エポキシ樹脂をマトリクス とした材料に関しては，水および硫酸浸せき後の弾性率

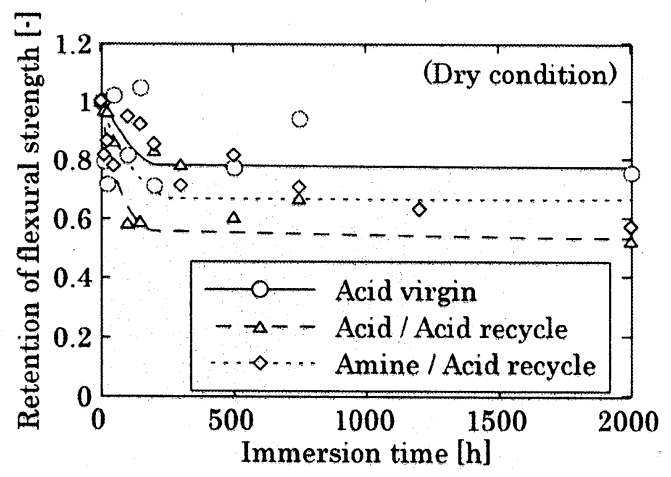

Fig. 3. Retention of flexural strength after immersion test in water at $80^{\circ} \mathrm{C}$ for the materials of which matrices are epoxy resin cured with acid anhydride.

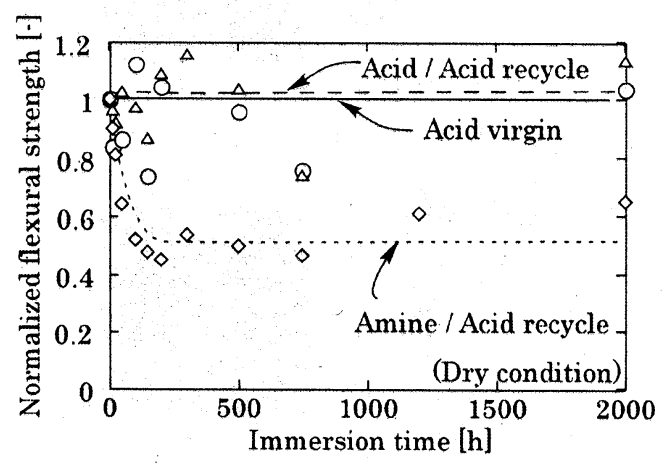

Fig. 4. Change of normalized flexural strength after immersion test in $30 \mathrm{wt} \% \mathrm{H}_{2} \mathrm{SO}_{4}$ at $80^{\circ} \mathrm{C}$ for the materials of which matrices are epoxy resin cured with acid anhydride. 
の変化はほとんど見られなかった。

酸無水物硬化エポキシ樹脂の水による强度低下の原因 を調べるため，水に浸せきさせた樹脂試料の赤外線 (IR) 吸収スペクトル分析を行ったが，IR チャートの浸せを前 後の変化は微弱であった。たとえば, ポリアミドの場合 にも水の浸入によって湿潤強度が著しく低下するが, ${ }^{11)}$ 乾 燥によって浸せき前の強度に回復する。これは，水分子 が分子鎖間に介在して分子鎖せグメント間の結合を弱め ることにより，可塑剤として作用するためであり, ${ }^{12}$ 通常 このような変化は可逆的である。しかしながら, 本研究 で扱った酸無水物硬化エポキシ樹脂では, 乾燥強度も低 下していることから, 分子鎖中のエステル結命の加水分 解などによって, 部分的に分子鎖の切断が起きていると 推測される。

次に，材料内への硫酸の浸入を調べる目的で，エネル ギー分散型 X 線分析装置 (EDS) を用いてイオウ (S) 元素 の检出を試みた。攵の結果を走査型電子顕微鏡 (SEM) 写真とともにFig. 5 に示す。元素分析の図 (右側)では, $\mathrm{S}$ 元素が多く存在する場所の輝度が相詨的に高くなって
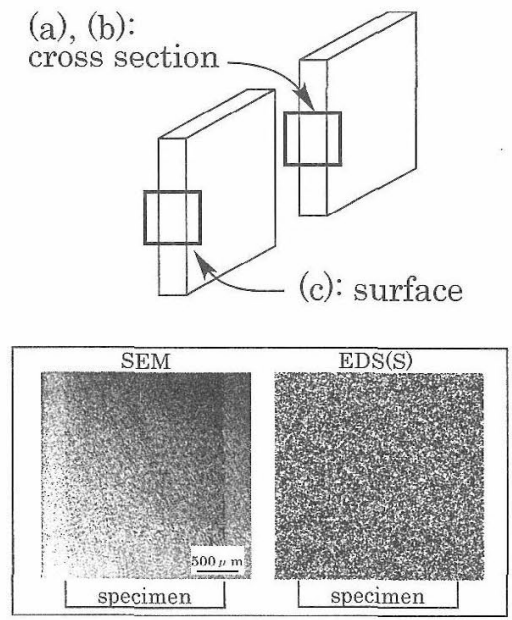

(a) Acid/acid recycle, cross section.

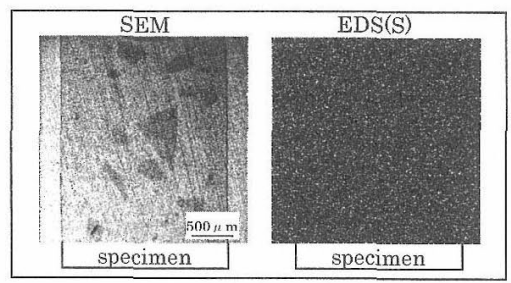

(b) Amine/acid recycle, cross section.

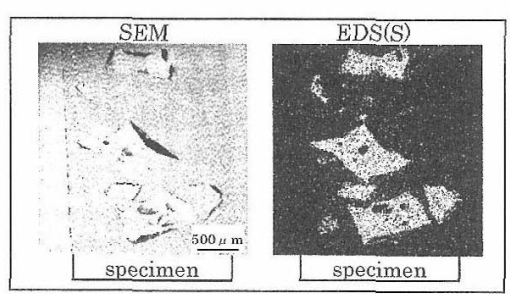

(c) Amine/acid recycle, surface.

Fig. 5. Scanning electron micrographs and sulfur element mapping images of the materials after 2000 hours immersion in $30 \mathrm{wt} \% \mathrm{H}_{2} \mathrm{SO}_{4}$ at $80^{\circ} \mathrm{C}$.
いる. Fig. 5 (a) は酸/酸リサイクル材の切断面の分析 結果の一例であるが, 忉料内部には S 元素は全く観察さ れておらず，硫酸が材料内部には浸入していないことが わかる。酸硬化バージン材においても同様の結果であっ た。一方，アミン/酸リサイクル材の切断面についても Fig. 5 (b)に分析結果を示したが，この場合にも材料内部 にはS元素は観察されなかった。㔯こで，試験片の端面 (すなわち表面. Fig. 5 の上図を参照.) 苞直接観察した ところ, Fig. 5 (c)に示したようにアミンフィラーの存在 する部分に $\mathrm{S}$ 元素が観察され，表面に露出している粒子 には硫酸が浸入していることが確認された。これらの分 析結果はFig.4の強度低下をよく裏付けており，硫酸に よって劣化を受けるのは主として表面近傍のアミンフィ ラーであることが明らかになった。

\section{3・2 アミン硬化エポキシ樹脂をマトリクスとする材 料の腐食挙動}

アミン硬化エポキシ樹脂をマトリクスとする 3 種類の 材料すなわち，アミン硬化バージン材，酸/アミンリ少 イクル材，アミンノアミンリサイクル材の実験結果につ いて述べる。アミン硬化エポキシ樹脂は耐酸性が低いの が特徴である。

$80^{\circ} \mathrm{C}, 30 \mathrm{wt} \%$ 硫酸水溶液に浸せきした捘の試験片の様 相を観察したところ，わずれの材料においても時間の経 過とともに試験片が濃く変色し，200 時間程度でほぼ黑 色になった。また，試験片は顕著に膨潤しており，厚さ が増していた。試験片表面を注意深く観察すると，いず れの材料においても，500時間程度でブリスター（膨れ） の発生が確認された。また，酸/アミンリサイクル材で は，試験片吉面にディンプル状の小さなくぼみが観察さ れた。これは，マトリクスが膨潤するのに対し，充てん したフィラーが膨潤しないために生じたものである。

Fig. 6 は湿潤重量打よび乾燥重量の経時変化を示した ものである。まず，湿潤重量に着目すると，浸尤さ直後 から急激に重量が増加し, 約 300 洔間で最大に達し, 吕 の後ほぼ、定となっている。3種類の材料の湿潤重量の 相違は少なかった，乾燥重量についても浸せき直後から

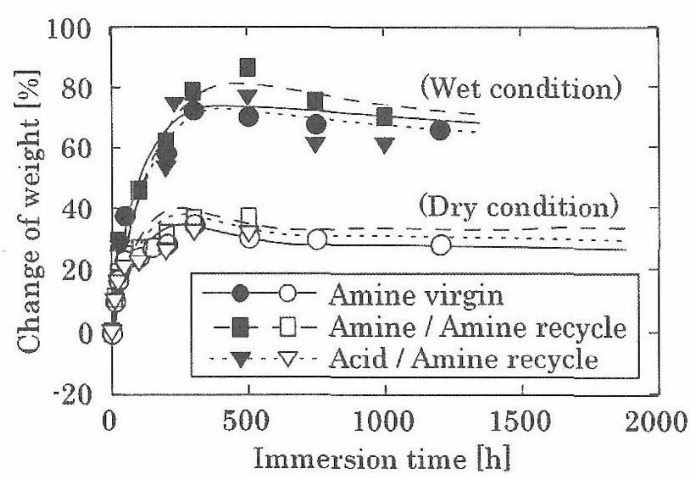

Fig. 6. Weight change after immcrsion test in 30wt\% $\mathrm{H}_{2} \mathrm{SO}_{4}$ at $80^{\circ} \mathrm{C}$ for the materials of which matrices are epoxy resin cured with amine. Solid symbols are measured under wet condition and open symbols indicate dry condition. 
増加し，約 300 時間で一定值に達した。乾燥状態では， 水はほぼ完全に除去されているので，乾燥重量に抢ける 增加分は硫酸分子の浸入によるものである。

Fig. 7 は, アミン硬化エポキシ樹脂をマトリクスとす る 3 種類の材料について, 試験片厚さの経時变化を示し たもので，膨潤によって厚さは浸せき直後から著しく増 加し，約 300 時間で一定值になった。この場合の試験片 の厚さは公称 $2 \mathrm{~mm}$ であるので, 約 1.5 倍に増加してい ることがわかる。厚さに関しても，材料の種類の違いの 影響は小さかった。

これら 3 種類の材料の湿潤曲げ強度保持率を求めたと ころ，いずれの材料においても浸せき直後から大きく減 少し，浸せき㣪約 50 時間でほぼ一定值（曲げ強度保持 率で約 0.2 ）となっていた。このような強度低下は水の浸 入による可塑化の影響である場合が多い。そこで，これ らの材料について, 乾燥曲げ強度求めた結果を Fig. 8 に示す。図より，乾燥によって浸せき初期の強度は顕著 に回復しており，湿潤強度の低下が可塑化の影響であっ たことが示唆される。Fig. 8 を詳細に見ると，浸せき開 始から約 75 時間が経過するまでの乾燥曲げ強度は 1 以 上の值となっており, 浸せき前の強度よりも大きいこと がわかる。このような現象は熱硬化性樹脂においてはし ばしば観察されるもので，以下の理由による。まず，樹

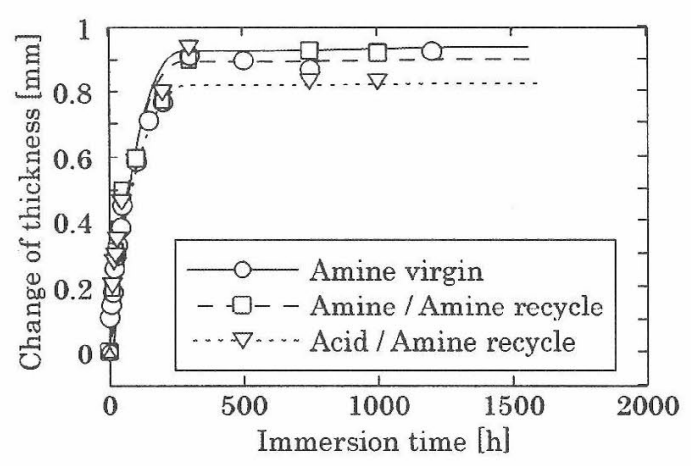

Fig. 7. Change of thickness of specimens after immersion test in $30 \mathrm{wt} \% \mathrm{H}_{2} \mathrm{SO}_{4}$ at $80^{\circ} \mathrm{C}$ for the materials of which matrices are epoxy resin cured with amine.

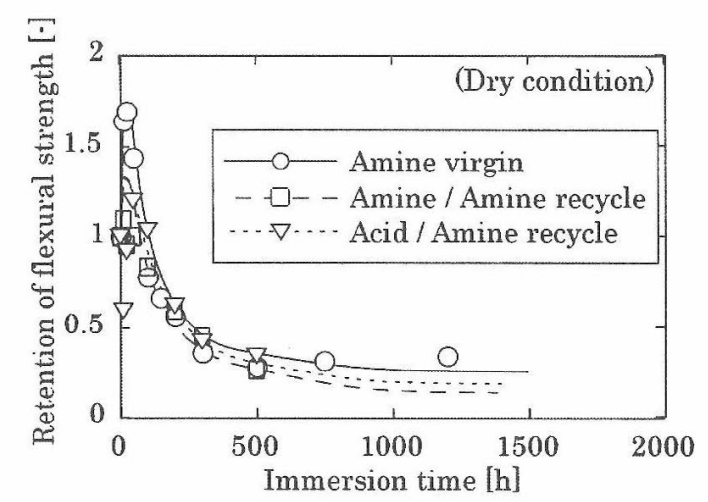

Fig. 8. Retention of flexural strength after immersion test in $30 \mathrm{wt} \% \mathrm{H}_{2} \mathrm{SO}_{4}$ at $80^{\circ} \mathrm{C}$ for the materials of which matrices are epoxy resin cured with amine.
脂中には必ず未反応の硬化剈やエポキシ基などが放存し

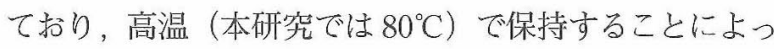
てこれら未反応基による架橋が進むことが挙げられる。 また，ぜい性的な材料の場合，曲げ試験時の破壊は試験 片表面の微小き裂から発生するが，環境液の浸入によっ て微小き裂の存在する領域が延性化するためにき裂先端 近傍の応力集中が緩和されたり，表面からの材料の溶出 によって微小き裂がすべて消滅し，極めて平滑な表面が 形成されたりすることによるものである。一方，75 時間 以降では乾燥強度保持率も 1 以下の值となり，浸せき開 始後 500 時間では約 0.3 まで低下している。これは，極 端に材料が膨潤することにより荷重を保持できなくなっ ていることによるものと考えられる。また，浸せき時間 が長くなるにしたがって，樹脂中のエステル結合の加水 分解反応など，分子鎖の開裂が起こっている可能性があ るが，化学的な分解を裏付けるデータは得られなかった。 アミン硬化エポキシ樹脂の硫酸水溶液による腐食ではIR チャートの変化が観察されにくく, ${ }^{13)}$ 強度の低下が膨潤の 影響のみによるものなのか，分子鎖の開裂が起こってい るのかについては，より詳細な検討が必要である。

$80^{\circ} \mathrm{C} ， 30 \mathrm{wt} \%$ の硫酸水溶液に 10 時間浸せきした酸， アミンリサイクル忉およびアミンノアミンリサイクル材 についてX線元素分析を行った結果を Fig. 9 に示守。ま ず,Fig. 9 (a)のアミンノアミンリサイクル材について見 ると, 試験片表面から約 $500 \mu \mathrm{m}$ の深さまでの領域に均 一にイオウ (S) 元素が存在していることがわかる。アミ ン硬化バージン材についても全く同様であった。一方， Fig. 9 (b)の酸/アミンリサイタル材では, 酸フィラー内 にはS 元素が検出されず，硫酸が酸フィラーを避けて浸 入していることがわかる。粒子近傍の様子をより詳細に 観察したところ，巨視的な硫酸未浸入領域のフィラーノ マトリクス界面へ硫酸の浸入は見られず，また，粒子の 存在により硫酸の浸入が抑止されている様子も見られな

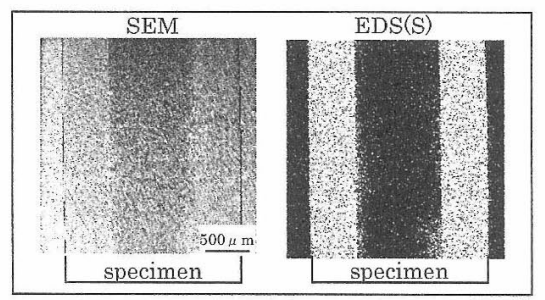

(a) Amine/amine recycle.

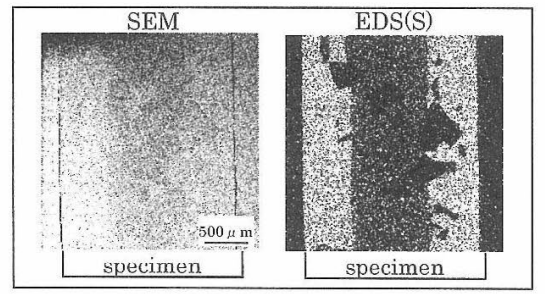

(b) Acid/amine recycle.

Fig. 9. Scanning electron micrographs and sulfur element mapping images of specimens after 10 hours immersion in $30 \mathrm{wt} \% \mathrm{H}_{2} \mathrm{SO}_{4}$ at $80^{\circ} \mathrm{C}$. 
かった. X 線元素分析の結果から, いずれの材料におい ても, 約 40 時間で硫酸が材料の深さ方向の中央部に到 達していた. これらの結果から, アミン硬化エポキシ樹脂 をマトリクスとした材料系の硫酸環境下での腐食に関し ては, バージン材とリサイクル材の違いや粉砕フィラーの 種類の違いの影響がほとんどないことが明らかになった。 著者らのこれまでの研究により，アルカリ水溶液中の腐 食に関しては，粉砕フィラーの種類の影響を顕著に受け る.9)しかしながら硫酸環境下については, マトリクスであ るアミン硬化エポキシ樹脂への環境液の浸入が極めて速 いため，界面の影響が表れなかったと考えられる。なお， 環境液の浸入が Fick 型の拡散によるものであれば，S 元 素は分布を持って観察されるはずであるが, 本研究では 均一分布であった.これは, 環境液の浸入によって樹脂 の膨潤が起こり，膨潤領域での拡散係数が大きくなるた めに起こると考えられ，このような現象は熱硬化性樹脂 への環境液の浸入においてしばしば観察される現象 ${ }^{14)}$ ある。

以上のことから，粉砕粒子充てんリサイクル材料の耐 食性は樹脂単体と同等の場合もあるが，材料と環境との 組み合わせによっては著しく劣化する場合があるため, このタイプのリサイクル材を使用する場合には，比較的 軽度の腐食環境であっても腐食劣化に十分注意する必要 がある。

\section{4 結 論}

耐酸性の高い酸無水物硬化エポキシ樹脂と耐酸性の低 いアミン硬化エポキシ樹脂をそれぞれ粉砕し，粒子を同 じ樹脂あるいは異なる樹脂に充てんしたリサイクル材の $80^{\circ} \mathrm{C}, 30 \mathrm{wt} \%$ 硫酸環境下での腐食挙動について検討を行 った結果，以下の知見を得た。

（1）酸無水物硬化エポキシ樹脂をマトリクスとした場 合, 樹脂単体, 酸無水物硬化エポキシ樹脂の粉砕粒子を 充てんした材料，アミン硬化エポキシ樹脂の粉砕粒子を 充てんした材料のいずれについても浸せき直後に湿潤重量 がわずかに増加した．いずれの材料においても曲げ強度の 低下が観察されたが，水中に浸せきした場合にも同様に 強度低下したため, 水浸せき後の強度で規格化した曲げ 強度を求めたところ, 樹脂単体および酸無水物硬化エポ キシ樹脂フィラーを充てんした材料では硫酸水溶液への 浸せきによる規格化曲げ強度の低下がほとんど見られな かったのに対し，アミン硬化エポキシ樹脂フィラーを充て
んした材料では大きく低下していた．X 線元素分析によ り，表面に露出したアミン硬化エポキシ樹脂フィラーには 硫酸が浸入していることが確認され, 粒子の劣化によっ て規格化曲げ強度が低下していることが明らかになった。

（2）アミン硬化エポキシ樹脂をマトリクスとした場 合, 樹脂単体, 酸無水物硬化エポキシ樹脂の粉砕粒子を 充てんした材料，アミン硬化エポキシ樹脂の粉砕粒子を 充てんした材料のいずれについても浸せき直後に湿潤重 量および厚さが顕著に増加した。乾燥後の曲げ強度保持 率は，浸せき後やや増加した後減少に転じ，浸せき開始 後 500 時間で曲げ強度保持率は約 0.3 に低下した.X 線 元素分析の結果，いずれの材料においても硫酸が素早く 材料内部に浸入していることが明らかになった． 3 種類 の材料について, 強度低下および硫酸浸入挙動に明確な 相違は表れなかった。

\section{参 考 文 献}

1) T. Itoh, T. Yokoi, K. Sekiyama, N. Kawamura and Y. Mishima, J. Thermoplastic Composite Materials, 7, 42 (1994).

2 ) 小島 昭, 宮下喜好, 吉川高雄, 材料科学, 31, 123 (1994).

3 ）星野守宏, 第 28 回 FRP シンポジウム講演論文集, 10 (1999).

4 ）仙北谷英貴, 久保内昌敏, 押田良隆, 津田 健, ネットワ ークポリマー, 23, 72 (2002).

5 ) 仙北谷英貴, 久保内昌敏, 津田 健, 阿部茂輝, 新井和吉, ネットワークポリマー, 22, 83 (2001).

6) 曹 宗焕, 久保内昌敏, 津田 健, 材料科学, 36, 272 (1999).

7 ）井波美千代, 仙北谷英貴, 久保内昌敏, 津田 健, 化学 工学会第 66 年会研究発表講演要旨集, K204，468（2001）.

8) 津田 健, 久保内昌敏, 日本海水学会誌, 52, 14 (1998).

9 ）仙北谷英貴，白石文洋，久保内昌敏，津田 健，第 52 回 ネットワークポリマー講演討論会講演要旨集, 64（2002）.

10) 白石文洋, 仙北谷英貴, 久保内昌敏，津田 健，46th FRP CON-EX 2001 講演要旨集，113（2001）.

11）仙北谷英貴，久保内昌敏，岡村孝司，津田 健，北條英 光, 材料と環境, 49, 494 (2000).

12) 北條英光, 荒井耕一, 材料科学, 12, 65（1975）.

13）久保内昌敏, 津田 健, PETROTECH, 19, 410 (1996).

14) Y. Dutheillet, M. Mantle, D. Vesely and L. Gladden, J. Polym. Sci., Part B: Polym. Phys., 37, 3328 (1999). 